\title{
NUANCES OF CHETTIAR FINANCING AT BRITISH MALAYA, C. MID-1870s TO EARLY 1890s
}

\author{
Amarjit Singh
}

\begin{abstract}
Moneylending and indigenous banking is often associated with the Nattukottai Chettiars. However, a long depression from the mid-1870s to early 1890s reveals a more nuance perspective of their financing at British Malaya. They not only had close business connections with Chinese tycoons, colonial officials, lawyers, sultans, penghulus, ship captains, shopkeepers and farmers. Evidently, colonial officials and Chinese tycoons also colluded with them in business transactions. In addition, their diverse operations comprised mortgages, pawnshop loans and new credit instruments like chetty's insurance bond as well as securing salaries and pensions through powers of attorney. By the early 1890s their entourage of credit and collateral included wages, ships, hotels, land, property, limekiln factories, coffee bags, pearls and even bullock carts.
\end{abstract}

\section{Introduction}

A long depression createda global financial lacuna from the mid-1870s to early 1890s giving the Nattukottai Chettiarsa minority mercantile community active in informal finance significant opportunities at British Malaya. ${ }^{1}$ Being itinerants or mobile operators in transit, they possessed a variety of financial instruments in demand at the informal merchant exchanges or bazaars between Madras and British Malaya. Their money lending, pawn broking, money exchange and chetty's insurance bond products allowed the Chettiars to not only establish close networks with colonial officials, Chinese tycoons, sultans, penghulus, ship captains, shopkeepers and revenue farmers. Some also colluded with colonial officials to receive important privileges and rewards. As a result, they accumulated substantial assets from the mid-1870s to early 1890s at British Malaya.

\section{Origin}

The Nattukottai Chettiars are often associated with city dwellers from the Tamil word nagaram or simply residents in market towns or nakarams. Early Tamil Brahmi inscriptions refer to them as vanigar or vaisya merchants. The word Chetty is also a title kings bestowed on merchants during the Sangam period. Chelis, Chetijs, Chetus, Chetins, Chatis, Chatus, Chitty and the latter day nomenclature of Nattukottai Chettiars are other names ascribed to them. ${ }^{2}$

In effect, nattu denotes rural land and kottai means a fort. These are apt terms to describe the Nattukottai Chettiars. They built fortress like homes located in Chettinad comprising nine kovils or clans with 25 gotrams or sub-castes. From the late $19^{\text {th }}$ to mid- $20^{\text {th }}$ century, they settled in 78 villages, of which 58 are in Ramnad district and the rest in Puddukottai state. When the Suez Canal opened by the 1870s, they expanded their informal financing operations using vilasams or initials of family names amongst partners in firms across different regions. ${ }^{3}$

\section{Informal Finance}

Informal finance is indeed notable among the Chettiars in Madras, Ceylon, Burma and British Malaya after the 1870s. Money lending is central to the studies of Paul H. Kratoska, Hans-Dieter Evers, Jayarani Pavadarayan, Heiko Schrader, Kernial Sandhu, S. Arasaratnam, 
Raman Mahadevan, Rajeshwary Amapalavanar Brown and Umadevi Prabharan. ${ }^{4}$ Likewise Edgar Thurston, Lakshmi Chandra Jain, V. Krishnan, U. Tun Wai, W. Weersooria, ${ }^{5}$ Michael Adas, Philip Siegelman, J.R. Andrus, C.L. Cooper, Christopher Baker, ${ }^{6}$ Medha Malik Kudaisya and $\mathrm{Ng}$ Chin Keong also elaborate these aspects. ${ }^{7}$

Ethno-historians and anthropologists for their part view culture and religion, kinship and kingship as significant Chettiar contributions. ${ }^{8}$ David West Rudner's exceptional research addresses "caste capitalism and corporacy" as a crucial link between religion, kinship, kingship and merchant banking. ${ }^{9}$ Commerce, finance and enterprise are further themes elaborated in recent studies by Clifford Geertz, Rajat Kanta Ray, Ashin Das Gupta, C.A. Bayly, Thomas A. Timberg, C.V. Aiyar, Claude Markotvits and Sean Turnell. ${ }^{10}$ Christine Dobbins relies on the works of socio-economic theorists on imperial history ${ }^{11}$ to contend they are a conjoint community of moneylenders and merchant bankers deriving their essence from spiritual sources. J.C. Van Leur, Ferdinand Braudel and Wu Xiao An highlight focus on networks in Southeast Asia. In fact, Wu's case studies on Chinese networks in Kedah and Penang refer to Chettiar loans made to the Chinese. ${ }^{12}$

\section{Chettiar Mercantile Collaborators}

There is no doubt that Chettiar mercantile collaborators increased their networks at British Malaya by the 1870 s through their itinerant or mobile operations. Scholars well document the functions of collaborators establishing networks for mercantile pursuits in colonial regimes. For example, C.M. Turnbull, Nicholas Tarling, V.T. Harlow, C. Trocki, B.W. Andaya and $\mathrm{Wu}$ Xiao An thoroughly cover the role of Europeans as "indigenous local collaborators" at British Malaya. ${ }^{13}$ However, itinerant mercantile Chettiar collaborators were equally important to colonial officials. They were important non-European middlemen serving as a go-between or intermediary to local mercantile rulers and their local chiefs. This was particularly apparent whenever they were in transit at the peripheral merchant exchanges of Madras, Ceylon, Burma, Acheen and British Malaya. More significantly, the Chettiars also had distinct advantages over European middlemen because they were usually more familiar with local customs, habits and languages in peripheral merchant exchanges. ${ }^{14}$

Accordingly, it is not surprising that the financing activities of the Chettiars proved to be substantially more important than the credit activities of European mercantile banks within the context of British Malaya. For example, reports from the Burma Provincial Banking Enquiry Committee show close to 700 Chettiar firms in British Malaya far exceeding the 450 in Ceylon and 105 in Cochin China respectively. For that matter, the 295 Chettiar firms in Burma also appear to carry the most amount of business with their partners in British Malaya as table 1 outlines below:

Table 1: Regional Burmese Chettiar Firms in Partnerships with other Colonies

\begin{tabular}{cc}
\hline Region & Number of Firms in Partnership with \\
& Burma \\
\hline British Malaya & 141 \\
Ceylon & 65 \\
Madras & 62 \\
Cochin-China & 27 \\
Total & 295 \\
\hline
\end{tabular}

Source: Report of the Burma Provincial Banking Enquiry Committee, "Banking and Credit in Burma," BPBEC, vol. I. Rangoon: Suprintendent of Government Printing, 1930. p. 191. 
More significantly, mercantile exchange banks often depended on the Chettiars for their financial strength and networks in British Malaya during the mid-1870s to early 1890s. A case in point were 28 Chettiar firms compared to only 4 mercantile exchange banks at Singapore in 1883 as proof of their financial strength at British Malaya. ${ }^{15}$

\section{Impact of Long Depression}

By the mid-1870s, a long depression known as the panic of 1873 further exacerbated Chettiar finances and the collateral they secured in British Malaya. In Britain, for example, the long depression invoked two decades of stagnation and deflation until 1896. It weakened the economic resources of the British Empire in its colonies leading up to the First World War. In a space of two decades from 1873 to 1896 , growth rates fall sharply from $4.3 \%$ to $2.9 \%$ in Germany, from $6.2 \%$ to $4.7 \%$ in the United States and from $3 \%$ to $1 \%$ in Britain increasing unemployment levels as liberal economist John Maynard Keynes observes. ${ }^{16}$

While the economic slow down from the long depression at British Malaya inevitably affected the Chettiars, it paradoxically also offered them new opportunities. Their informal financing gained wider demand from Chinese operating revenue farms and other ventures. The bulk of the mercantile community struggled to secure credit as mercantile exchange banks hesitated to finance new ventures and incur additional debts. The nexus saw a desperate shortage of financing leading even Allie Iskandar Shah, Sultan of Johore into substantial debts by the 1870 s.

\section{Sultan Allie Iskandar Shah and the Chettiars}

Even before the long depression, court documents show the financial clout and contacts of the Chettiars with Sultan Hussein Shah of Johor, his wife the Queen Dowager, the King of Perlis and Quedah and Syed Saban, King of Runbow. ${ }^{17}$ Like his parents, Sultan Allie Iskandar Shah of Muar too had financial obligations to the firm of Kavena Chana Shellapah Chitty. The \$53,000 loan from Shellapah Chitty's private finance agency to Sultan Allie Iskandar Shah "at a monthly at the rate of 15 per cent per annum amounted to $\$ 121,025$ after securing the payment of the principal sum and interest in the said bond." "18 Sultan Allie Iskander Shah pledged security and collateral to assign the payment of his father, Sultan Hussen's monthly pension of $\$ 500$ to Shellapah Chitty. Governor Murchison allotted it in 1840 in view of the destitute circumstances of Sultan Hussein's family. ${ }^{19}$ This monthly payment of $\$ 500$ from June 1861 to December 1876 saw Shellapah Chitty earn more than $15 \%$ in interest. ${ }^{20}$ In effect it amounted to $26 \%$ in interest as table 2 below shows:

Table 2: Interest paid by Sultan Allie Iskander Shah to Shellapah Chitty

\begin{tabular}{lll}
\hline Year & Amount Paid & Total \\
\hline 1861-1877, Monthly payment & $\$ 500$ & $\$ 90,000$ \\
1881, Outstanding principal and interest & & $\frac{\$ 121,025}{\$ 211,025}$ \\
Total & & $\$ 53,000$ \\
Loaned Amount & & $\$ 211,025$ \\
15 Year Percentage Earned & $398 \%$ \\
Total 15 Year Percentages & $26 \%$ \\
Yearly Average Percentage without compounding & & \\
\hline
\end{tabular}

Source: The computing here by writer, a former banker, is based on simplified calculations without compounding for ease of reference and understanding. 


\section{Chetty's Insurance Bond}

Not with standing contacts like Sultan Allie Iskandar Shah, the Chettiars also offered freight insurance on board ships. By the mid-1870s, they introduced a new credit instrument called chetty's insurance bond for vessels or ships. With shipping on the rise, chetty's insurance bond was a timely instrument for the mercantile community. This instrument benefitted the Chettiars significantly especially at a time when the colonies received a more proactive and independent role in commerce directly under the British Crown. ${ }^{21}$ It opened new outlets for the Chettiars to promote their new chetty's insurance bond credit instrument to the mercantile community keen on expanding their commercial activities.

Under chetty's insurance bond, ship captains or masters or owners borrow monies from the Chettiars at high interest rates. In exchange, the Chettiars received vessels as assignments for default payments. In doing so, "the Chetties usual way of dealing in insurance matters is to advance the money insured for, and get repayment thereof subject to risk." 22 Herein also lay the key difference between chetty's insurance bond and cargo insurance restricted primarily to goods. In contrast, chetty's insurance bond could gain them security of the ship itself pledged as collateral in the event of a default in payment. However, they also stood to lose their bond when ships got lost at sea as long as they were travelling on course to their destination. There was no such provision with cargo insurance that had to be paid one way or another. Notable examples using chetty's insurance bond included Armoogum Chetty's finance to Lee Cheng Tee and others from the vessel Black Diamond. They borrowed $\$ 4,400$ at an interest rate of $27 \%$ through a chetty's insurance bond contract at Singapore. Lee and his partners breached the covenant in their voyage by taking a deviation to Malacca where the ship was lost. The stipulation stating "voyages to and from Singapore, Penang, Acheen, Rangoon or Saigon" was quite clear and Armoogum Chetty received compensation for the default. ${ }^{23}$

However, Verappa Chetty lost out his insurance credit made to Joseph Charles Angles and Ventre for French mastered schooner vessel Charles Jules wherein the ship was genuinely lost at sea. ${ }^{24}$ The letter of the law governing chetty's insurance bond was really to protect ships and cargoes vulnerable to piracy. The Chettiars were willing to finance these cargoes and ships at high interest rates provided they received their principal monies when ships arrived safely with the cargoes. However, when they collided or veered off course in being taken by pirates, the Chettiars stood to lose their finances. There was nothing to prevent borrowers from colluding with pirates in refusing to honour repayments to the Chettiars although there were no official documents suggesting this was the case. Accordingly, it is clear that Chettiars did not always make money during the long depression years with some even resorting to trading in unlicensed articles.

\section{Trade in Unlicensed Articles}

By the 1870s, trade in unlicensed articles like opium, baang or cannabis, arms, gunpowder, fake coins and currencies together with the operation of hotels as brothels as well as gambling dens was not uncommon. Carl A. Trocki, James F. Warren, James R. Rush and Eric Tagliacozzo provide significant details on illicit activities within Southeast Asia under colonial regimes. ${ }^{25}$

To some extent, the advent of unlicensed articles and on board vessels without proper docking permits was already present from a relatively early period throughout the merchant exchanges of Aceh, Sumatra, Penang, Singapore and Malacca. These merchant exchanges saw increasing activities in the trade of unlicensed articles within the Dutch East Indies as well as British Malaya. A case in point was Candappa Chettiar, a mirasidar or land proprietor and owner of several vessels plying between Acheen, Penang and the Coromandel Coast. He traded at Tapoos, Sinkel and Soosoo within the jurisdiction of Acheen with local chiefs 
where he did not pay port duties. ${ }^{26}$ Candappa Chettiar brought opium, gunpowder, saltpetre and firearms against the decrees of the Johor Allum Shah, King of Acheen. This led Johor Allum Shah to retain Candappa Chettiar's Annapoorney country vessel for violating port dues, docking without a permit and engaging in opium and ammunition transactions against the King's decrees at Tapoos, Singkel and Soosoo. ${ }^{27}$

By the mid-1870s, transporting articles without the payment of port duties rose. Verappa Chetty was one apparently trading good grade baang or cannabis on board his vessels coming into Singapore, Penang, Malacca and Selangor without paying port dues. ${ }^{28} \mathrm{He}$ often had little difficulty bringing over supplies of baang by colluding with colonial officers allowing shipments of baang to embark at the merchant exchanges of Singapore, Penang, Malacca and Selangor. To some extent, it was "an open secret" that colonial officers earned monies from this trade. ${ }^{29}$ For example, Arthur J. Perks, the Land Revenue Collector of Klang allowed Verappa Chetty to transport such articles without the payment of dues. Arthur J. Perks evidently helped Verappa Chetty because he had borrowed $\$ 3500$ through a promissory note from Verappa Chetty that was still outstanding. ${ }^{30}$

Like Verappa Chetty, Kootyan Chetty was another involved in the baang trade in 1887 and 1888 respectively. He had taken loans from the Mercantile Bank of India for his financing operations from Madras and London to Calcutta, Penang, Singapore, Sourabaya, Batavia and Malacca. ${ }^{31}$ Yet, Kootyan Chetty traded in baang or cannabis at Larut farm in Perak as well as in Penang. He brought over five bales of baang worth \$1600 Spanish dollars on board his S.S. Orion in a transaction involving Bawasah Merican, clerk of the Pyre Dock Landing and Shipping Company at Penang. However, the fives bales of baang were duly intercepted and forfeited by the authorities despite being hidden in onion gunny bags and sailcloth on the ship. ${ }^{32}$

Even merchants operating gambling dens on revenue farms could not secure credit during the long depression. They leaned on the private finances of the Chettiars because mercantile exchange banks were not willing to dispense credit. For that matter, the Chettiars did not have to pledge collateral according to reports of bank inspectors at Madras, Malacca, Penang, Singapore, Hong Kong and Batavia. They could utilise monies from mercantile banks $^{33}$ to finance Chinese revenue farmers. For example, Ahvena Ravena Mana Aroomoogum Chetty financed the unlicensed activities of Lim Ah Hang, Ah Gee, Chop Lee Whatt and Tan Kim Cheng at Singapore in 1894. The colonial authorities seized from them not only opium, fake coins and currencies, but also gunpowder and arms hidden in pianos, kerosene tins and onion gunny bags. ${ }^{34}$

Life was not easy for revenue farmers like Lim Ah Hang, Ah Gee, Chop Lee What and Tan Kim Cheng. They faced difficult challenges to seek economic activities suitable for taxation, win contracts to collect taxes on revenue farms, recruit labour, produce goods and pay authorities a rent in the hope of enjoying substantial surpluses at the end of these processes. ${ }^{35}$ Under these financial constraints, they depended substantially on investments from Ahvena Ravena Mana Aroomoogum to finance their rice milling, shipping and farming operations.

With unlicensed articles on the rise, the colonial authorities passed several ordinances restricting the issue of licenses for arms, gunpowder, toddy, opium, baang or cannabis and other commodities on excise farms as well as bills of sale governing the transfer of title deeds. ${ }^{36}$ Nevertheless, these ordinances did little to deter such activities. Throughout the long depression years, it was clear some Chettiars were involved in the trade of unlicensed articles surmised at table 3 . 
Table 3: Sampling of Chettiar Finances, c. 1880-1894

\begin{tabular}{llll}
\hline Name & Activity & Location & Year \\
\hline Meyappa Chetty & Informer/No Pawnbroker license & Penang & 1880 \\
Mootiah Chitty & Informer/Stamp Ordinance & Singapore & 1881 \\
Sally Kundoo Chitty & Informer/Stamp Ordinance & Singapore & 1881 \\
Verappa Chetty & Opium, Baang or Cannabis & Selangor & 1884 \\
Kootyan Chetty & Baang or Cannabis & Penang & 1887 \\
Palaniappa Chitty & Hotel Chitty Brothel. Financing Yap Ah Loy & Selangor & 1888 \\
Kootyan Chetty & Baang or Cannabis at Larut Farm and S.S. & Perak & 1888 \\
& Orion & & \\
Coopang Chetty & Financing hotel. Excommunicated & Penang & 1888 \\
Ahvena Ravena & Financing Lim Ah Hang, Ah Gee and Chop & Singapore & 1894 \\
Mana Aroomoogum & Lee Whatt in opium farming and gambling & & \\
Chetty & dens Opium, gunpowder, arms, fake coins and & & \\
& currencies hidden in pianos, kerosene tins and & & \\
& onion gunny bags seized. & & \\
\hline
\end{tabular}

Source: Compiled from data at HMSCSS, vols. $i$-iv, SSSF, SSR, COR, PLCSS.

While Verappa Chetty, Kootyan Chetty and Ahvena Ravena Mana Aroomoogum Chetty were involved mainly with Chinese farmers, table 3 also highlights Chettiars assisting the colonial government to contain unlicensed activities as informers.

\section{Chettiar Informers Gain Rewards and Privileges}

Another significant aspect at table 3 shows Chettiars assisting colonial authorities at British Malaya as informers to curb unlicensed activities in exchange for gaining rewards and privileges. The network of spies and informers gathering intelligence across merchant exchanges in Burma, Ceylon, the Dutch East Indies and British Malaya is evident in Dutch and English records. ${ }^{37}$ Meyappa Chetty was among the earliest informers to the English colonial authorities at British Malaya. He was an informer on a breach of the Pawnbroker's Ordinance 7 of 1872 by Khoo Aing Hong and Puteh at Penang on December 13, 1880 who were operating pawnshops without a license. ${ }^{38}$ Meyappa Chetty was rewarded quite well with a monopoly of pawn broking licenses throughout British Malaya with some shops still active at what is now called Meyappa Chettiar Road in Singapore. ${ }^{39}$

In 1881, Mootiah Chitty and Sally Kundoo Chitty too received rewards for the information they provided on those prosecuted for failing to adhere to the Stamps Ordinance Act. Most of these Chettiars drafted legal conveyance documents pertaining to mortgages and were privy to all information about their clients in preparing these contracts. Given they were not bound by any confidential code, they were able to furnish information to the colonial authorities on any of their clients not paying stamp duties. Sally Kundoo Chitty and Mootiah Chitty furnished precisely such information and in exchange received rewards amounting to $\$ 1250$ Spanish dollars ${ }^{40}$ as figure 1 overleaf shows. 
Figure 1: Mootiah Chitty and Sally Kundoo Chitty paid \$1250 Spanish dollars as informers

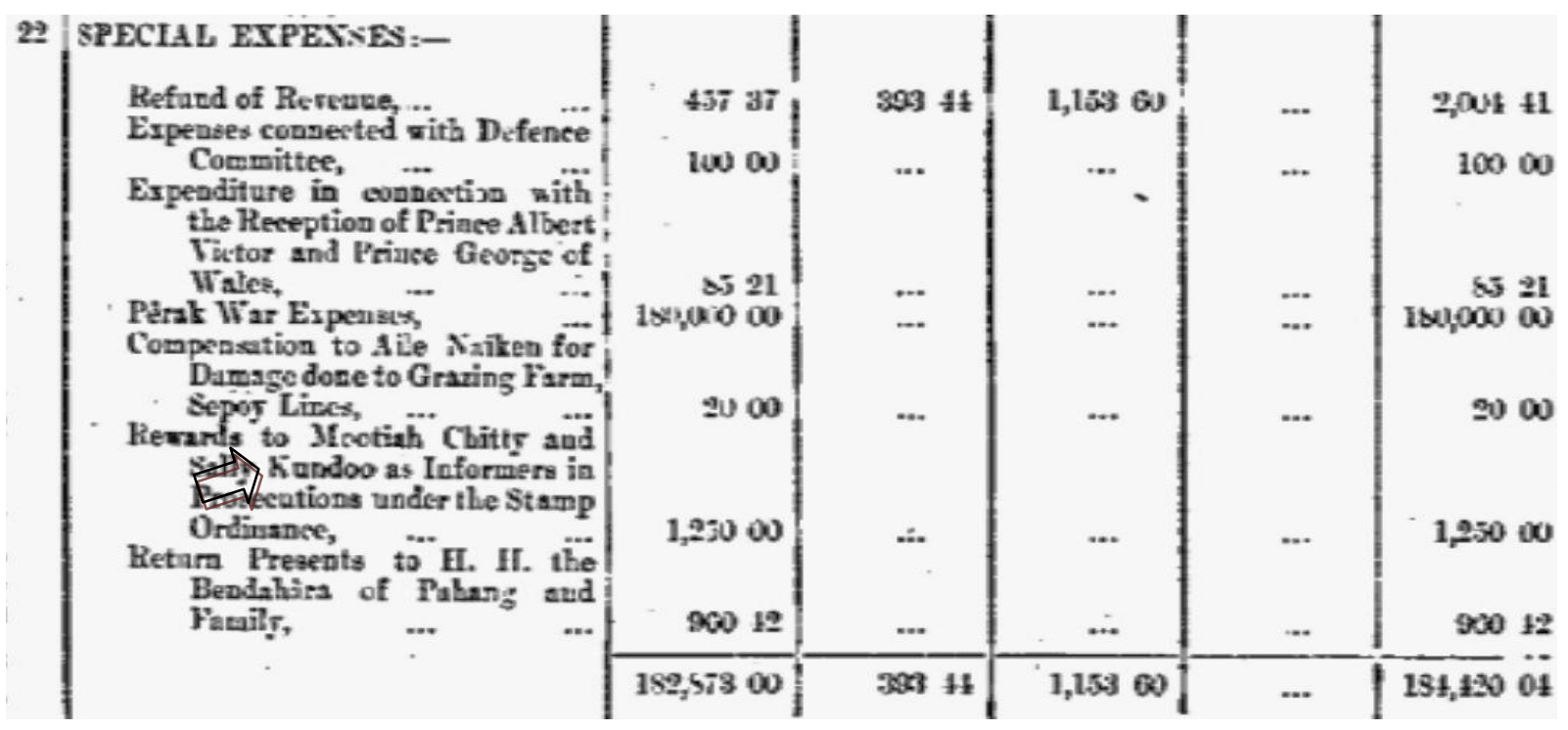

Source: Straits Settlements Detailed Expenditure 1881, Proceedings of the Legislative Council of the Straits Settlements [PLCSS], 1882, Colonial Office Record [COR] 275/27, Singapore Government Printing Office Straits Settlements 1882, p. 219.

From figure 1, it is worth noting that colonial officials wrote off the rewards for the information the Chettiars provided under Special Expenses from the allocated budget. The precedent of utilising Chettiars as informers offers insights into how these intermediaries or compradors had vital networks making them useful sources of information to the colonial authorities. In rendering finance, the Chettiars had close contact with their borrowers and were privy to their confidential matters in order to approve their loans. The inside information they had access to what was important for the colonial authorities especially with regards to Chinese involved in multiple syndicates, guilds and triad societies. For these reasons, colonial officials valued the information furnished by the Chettiars. It also explains why they were given special privileges on revenue farms, pawnshops as well as in furnishing private loans to colonial officials. While colonial official achieved some measure of success through informers to contain unlicensed activities, it was not easy to redress the on-going collateral losses to the Chettiars.

\section{Securing Collateral Via Asset Accumulation}

In effect, the Chettiars secured significant collateral via asset accumulation from their private loans throughout the long depression. They seized properties, ships and commodities secured through defaults on credit and mortgage loans. There are several colonial office records, stamp office files, state secretariat files and legal records on Chettiar legal suits for loan defaults in court proceedings. The Chettiars signed legal covenants and deeds with rice shopkeepers, nacodahs or ship captains and local farmers for their loans. For example, rice shopkeepers, Kam Choo Poh, Lim Swee Choe and Lim Chee Choo relied on the Chettiars for credit. ${ }^{41}$ Likewise, tradesmen such as Kang Oon Lock operating Teng Thye in George Town, Penang also received credit from Coomarapah Chetty, ${ }^{42}$ whilst Meyappa Chetty financed Khoo Been Teen. ${ }^{43}$ In fact, on October 15, 1881, Mohamed Sham mortgaged lands and hereditaments at Rope Walk Lane in Penang to secure the repayment of a loan of \$2000 Spanish dollars at $12 \%$ interest from Komorapah Chetty. ${ }^{44}$ 
Similarly, Sheikh Abbas and Hadji Abdul Samad, "traders" and "owners" of a "steam launch S.L. Rapid" in Singapore pledged their ship as collateral. They borrowed $\$ 1500$ Spanish dollars from Moona Navena Raman Chitty on March 30, 1883 with "a covenant" to repay the loan in instalments of principal and interest within twenty calendar months. ${ }^{45}$ With two outstanding payments of \$291.78 Spanish dollars and \$224.62 Spanish dollars still owing on August 1, 1883, Raman Chitty seized their ship and its contents through legal proceedings. Apparently, Sheikh Abbas and Hadji Abdul of the S.L. Rapid vessel at Singapore were willing to pay $18 \%$ interest and bear the risk of losing their ship and its contents to Moona Navena Raman Chitty. On March 18, 1884, Selangor Resident, F.A. Swettenham made it clear though that the ship needed a title deed to qualify as a mortgage. He therefore requested Raman Chitty to obtain the title deed from the Stamp Office in Selangor. The purpose was to both minimize fake title deeds and also generate revenue for the government from stamp duty payment for the title deeds. Once Raman Chitty produced the proper legal documents, the Collector of Klang "amicably concluded" between the parties on April 3, $1884{ }^{46}$

However, the colonial authorities did not always make exceptions for non-compliance to colonial ordinances, laws and regulations especially on title deeds for any property. This was particularly true in the case properties pledged for Chettiar loans without the knowledge of a spouse. In 1885, an interesting loan in this aspect involved two women Nonia Lim Chee and her friend Nonia Gek. Letchmann Chetty loaned \$600 Spanish dollars to Nonia Lim and Nonia Gek claiming to be widows. In fact, Nonia Lim was the wife of Siamese Doctor Nain Boon Keow. She has bad gambling debts and mortgages her property at Bridge Street in Penang for a $\$ 600$ Spanish dollars loan from Letchmann Chetty. In the process Letchmann Chetty sold the property at an auction at a cheaper price, which Doctor Nain Boon Keow unfortunately only discovered after the property was sold. ${ }^{47}$ To pre-empt such abuses in the transfer of title deeds, the colonial authorities therefore initiated a Bill of Sale Ordinance to register property mortgages. Even then, desperate borrowers pledged properties to the Chettiars with fraudulent title deeds just to get loans. This was certainly the case with Meyappa Chetty's loan to Doral and Lesslar who had fraudulent title deeds in $1886 .{ }^{48}$

To protect themselves from unwanted losses, the Chettiars too used the Bill of Sale Ordinance in court to request advance payments of interest rates on their loans. At times they would not release a property until their full payments were made. In 1888, Narainen Chetty and his partners took possession of and sold the property belonging Kundoo Mah before her estate executor Jenaiboo could do anything. Likewise, Shenayah Chetty secured the lands of Veena Sultan Mahomed for outstanding balances of $\$ 6378.65$ Straits rupees on a statutory mortgage. ${ }^{49}$ Apart from properties andchattels or moveable items the Chettiars also seized tonkangs or small boats. Despite the Bill of Sale Ordinance prohibiting chattels as fixed property, Savavathy Chetty secured thetongkangs belonging to Nagore Gunny. ${ }^{50}$

\section{Hotels and Excommunication}

In addition, Chettiar loans also included the pledging of hotels as collateral. Besides Palaniappa Chitty's loan to Kapitan China Yap Ah Loy for Hotel Chitty Brothel, Coopang Chetty also financed brothels. However, the Chettiar community excommunicated the latter for dabbling in loose and immoral conduct.

By April 1888, Coopang Chetty renowned for his financing activities at Bagan Tuan Kechil in Penang invested monies in hotels and also sold goods to the locals. When they defaulted with their loans, Coopang Chetty resorted to engage in actions that were disparaging to the image of the community. As a result, the body of elders in the panchayat or kovilvasal mariyal in a temple council led by Veera Padiachee, the Headmen disciplined Coopang Chetty. They instructed Ramanjuloo, Coopang Chetty's brother-in-law to get him to refrain from his loose conduct affecting the community at Bagan Tuan Kechil. ${ }^{51}$ 
Subsequently, the body of elders sounded the cymbals of the "tom tom" or drums to make a public announcement excommunicating Coopang Chetty from the community at Tuan Bagan Kechil. They did not allow anybody in the community to have further dealings with him on any financial transactions and also asked him to pay \$25 Spanish dollars for the convening of the meeting by the body of elders. Inevitably, Coopang Chetty refused to comply and instead took up a slander charge against the body of elders. However, Judge J. Pellereau ruled against him on the matter. ${ }^{52}$

Perhaps more significant was Hotel Chitty Brothel owned by Palaniappa Chitty and leased to the famous Kapitan China or Headman, Yap Ah Loy. Kapitan China Yap took loan from Palaniappa Chitty in the amount of $\$ 6000$ Spanish dollars to cover his expenses in operating the brothel. Like Coopang Chetty in Penang, Palaniappa Chitty also invested his finances with Kapitan China in hotels used as brothels at Selangor. By 1888, F.A Swettenham, Resident Selangor approached Palaniappa Chitty to sell Hotel Chitty Brothel in an effort to rid the town of immoral vices within the vicinity of Kuala Lumpur. Given that Kapitan China Yap had been defaulting on his payments for several years, Palaniappa Chitty decided to sell Hotel Chitty Brothel through Swettenham's realtor Syed Zui for $\$ 3000$ Spanish dollars on October $8,1888 .^{53}$

While Coopang Chetty and Palaniappa Chitty financed hotels used as brothels in view of the challenging economic circumstances during this period, as a community, the Chettiars also stood firm on moral matters. They were prompt to stamp out any undesirable activities. In fact, the body of elders in the panchayat or kovilvasal mariyal at the temple council considered Coopang Chetty's actions to be unscrupulous in promoting loose conduct. They were not tolerating acts tarnishing the image and reputation of the community. Coopang Chetty's excommunication was a clear indication they would isolate and expel any member from the community partaking in immoral conduct at Tuan Bagan Kechil.

\section{Seizing Trinkets Through Pawnshop Loans}

Apart from financing ships, lands, properties and hotels, the Chettiars also dispensed pawnshop loans secured against assets such as gold and jewellery trinkets. They charged interest according to the urgency of the demand, the size of the loan, the duration of the debt and by the volume of demand for loans within a particular group or community.

A case in point was Raja Itam b. R. Eunos's pawnshop loan from Verappa Chitty wherein neither British Resident, F.A. Swettenham nor John Pickersgill Rodger, Acting Collector, Klang could do much to assist Raja Itam. ${ }^{54}$ Colonial officials may have collaborated closely with local rajas and penghulus or headmen in the Malay states. Yet they were equally conscious that they could not assist them on Chettiar loans. Haji Hassan, penghulu at Kampung Batu found out with his petition to the Resident of Selangor September 10,1889 pertaining to $\$ 130$ Spanish dollars he owed Haraina Chitty in a court judgment. ${ }^{55}$

The monopoly of Chettiar pawnshop leases at British Malaya was inevitable given they were proprietors of revenue farms. Besides acting as intermediaries in the collection of revenue on farms, they also received the right to operate pawnshops in British Malaya. ${ }^{56}$ There was no doubt that the Chettiars often paid higher for pawn loans vis-à-vis government credit institutions like the Straits Settlements Savings Bank. However, they also charged higher interest rates making it impossible for borrowers to retrieve their trinkets pledged as collateral. Yet borrowers still approached the Chettiars because they were also quite flexible in regularly allowing the postponement of payments and accepting a lower rate of interest depending on circumstances. They well knew that their clients needed the finance usually for consumption and not investments often in weddings, funerals or festivals. 


\section{Limekiln, Coffee, Pearls, Bullocks and Carts}

Brick, limekiln, coffee, pearls, bullocks and carts also featured in the entourage of Chettiar collateral. For instance, on March 5, 1889, Mah Jwee, owner of Brick Kiln at Batu Road "received" a "summons for $\$ 925.25$ Spanish dollars balance money lent on the suit of a Karpen Chitty." His appeal to William Edward Maxwell, Resident Selangor came to no avail as "the case was heard and settled by the Court". The keen interest of the Chettiars in limekiln was also evident in Baboo Mandore's dealings with Palaniappa Chitty and Chellapa Chitty. In fact, Baboo Mandore, himself a limekiln owner had to seek assistance from the Acting British Resident on August 6, 1889 to resolve conflict in an agreement he made with the Chitties. ${ }^{57}$

Apart from limekiln for bricks, the Chettiars would also take commodity items that included coffee when payments were not made. On September 13, 1890, Ramasamy Valee petitioned W.E. Maxwell, British Resident Selangor to prevent Sivarama Chitty from taking his "8 bags of coffee seeds and 14 bags of dried coffee fruits worth $\$ 250$ Spanish dollars." However the Resident replied on September 18, 1890 that he referred Ramasamy's petition to the Chief Magistrate [Henry Conway Belfield]. ${ }^{58}$

Just as intriguing were pledges extended to other items like pearls, carts and bullocks. The Chettiars were in fact quite well known for the importing of bullocks and carts. They were pioneers in the use of this means of transportation just as they were with carriages and ponies. The import of a bullock by a Chitty at Pekan Baru in Pahang was just one example. It revealed their involvement in not only importing these animals, but also providing finance to gharry wallahs or bullock cart drivers who were dependent on these resources for their means of livelihood. ${ }^{59}$

In one interesting transaction relating to carts and bullocks, Nagamuttoo Sarwag stood as "surety" on a bond his friend Chrisnamottoo Pillay signed for borrowing "a sum of Dollars $\$ 815$ including interest from Karupen Chitty. ${ }^{60}$ When payments were not forthcoming Karupen Chitty tried to recover "the remainder $\$ 144.53$ Spanish dollars" from the surety Nagamuttoo Sarwag and not from Chrisnamuttoo Pillay even though the latter took the loan. Furthermore, Karupen Chitty already took the property, land and pearls that were part of the bond fulfilment for security as collateral. ${ }^{61}$ Such actions suggest that some debtors transferred their liabilities to sureties who incurred the payments owing to the Chettiars.

\section{Powers of Attorney on Salaries and Pensions of Malay Rajas and Hajis}

In addition, the Chettiars also pledged the salaries and pensions of other leaders in the Malay community. Verappa Chitty lent monies through powers of attorney assigned to him on the salaries and pensions of several Rajas and Hajis. He claimed that over 15 years he had lent money to different Raja and Haji pensioners. In doing so, he secured powers of attorney to garnish their salaries and pensions when they failed to make payments. Among those who pledged their salaries and pensions to Verappa Chitty were the Rajas and Hajis in table 4 overleaf. 
Table 4: Amounts Owing to Verappa Chitty from his Powers of Attorney on Pensions and Salaries of Malay Rajas and Hajis, 1888-1892

\begin{tabular}{|c|c|c|c|c|c|}
\hline Name & Start Date & $\begin{array}{l}\text { Rate Per } \\
\text { Month } \\
\text { (Spanish } \\
\text { dollars) }\end{array}$ & $\begin{array}{l}\text { Duration of } \\
\text { Monthly } \\
\text { Instalments }\end{array}$ & $\begin{array}{l}\text { Monthly } \\
\text { Instalments } \\
\text { Received }\end{array}$ & $\begin{array}{l}\text { Monthly } \\
\text { Instalment } \\
\text { Owing }\end{array}$ \\
\hline Haji Mat Tahir & $\begin{array}{l}\text { December } \\
\text { 13th } 1888\end{array}$ & $\$ 200^{\circ 0}$ & 18 months & $\begin{array}{l}7 \text { months as at } \\
\text { June } 1889\end{array}$ & 17 months \\
\hline Raja Mansour & $\begin{array}{l}\text { November } \\
\text { 30th } 1888\end{array}$ & $\$ 15^{\circ o}$ & 20 months & $\begin{array}{l}8 \text { months as at } \\
\text { June } 1 \text { st } 1889\end{array}$ & 12 months \\
\hline Abdul Majid & $\begin{array}{l}\text { June 30th } \\
1888\end{array}$ & $\$ 10^{\circ o}$ & 40 months & 1 month & 39 months \\
\hline Raja Mohamed & $\begin{array}{l}\text { December } \\
19 \text { th } 1888\end{array}$ & $\$ 50^{\circ 0}$ & 20 months & $\begin{array}{l}7 \text { months as at } \\
\text { June } 1 \text { st } 1889\end{array}$ & 13 months \\
\hline Nacodah Alang & $\begin{array}{l}\text { July } \\
1888\end{array}$ & $\$ 20^{\circ 0}$ & 30 months & Nil & 30 months \\
\hline
\end{tabular}

Source: SSSF, 1957/00016063, Klang 2471/89, Power of attorney to Verappa Chitty by Abdul Majid to draw his pensions from 1-Jun-1889 to 30-Sep-1892.

From table 4, the Rajas and Hajis receiving pensions from the governmental authorities were vulnerable to the high interest rates they were paying to the Chettiars. This was seen from the extent to which many months of instalments were still overdue. In fact, Nacodah Alang had yet to make a single payment to Verappa Chitty. By 1890, Letchmann Chetty also secured wakaf land at No. 20 Pitt Lane through a power of attorney on his mortgage to Yacob and Nyah Hamzah. ${ }^{62}$

Accordingly, the use of powers of attorney on salaries, pensions as well as wakaf land therefore gave the Chettiars an additional avenue to secure collateral. They were acquiring assets from Malay leaders whilst also making Chinese towkays or tycoons liable for debts.

\section{Holding Towkays or Tycoons Liable for Debts.}

A further aspect of Chettiar financing included making towkays or tycoons liable for the loans they obtained from them. They were willing to negotiate with their defaulters, but were also well equipped with their documentation to secure what they needed when their payments were not forthcoming. Unlike Chinese triad societies using violence to resolve conflicts, the strength of the Chettiars lay in their understanding of English laws. They were well versed with the legal system having many prominent English solicitors such as Van Someren who represented them in many cases. ${ }^{63}$

Several towkays lost their means of livelihood attesting to why the Chettiars were not always conciliatory. On April 1, 1890, towkay or tycoon Chong Boo Hin petitioned the British Resident Selangor, W.E. Maxwell that he had a house on Batu Road for which he paid $\$ 1200$ Spanish dollars, adding this house was mortgaged to a Chetty named Annamallay for $\$ 600$ Spanish dollars. The mortgage was for 4 months. After seven months, the house was auctioned and sold two months later at less than half its value. However, A.T.D. Berrington, Chief Magistrate Selangor informed the Governor's Secretary on April 4, 1891 that the Chetty creditor's rights were clear and no concessions could be made. Despite Chong Boo Hin's to anger in the court, "nothing further was done in the matter." 64 
Likewise, the towkay [tycoon] or owner of a mine, Chong Ah Boo's petition before John Pickersgill Rodgers British Resident Selangor fared no better on May 22, 1891 with regards to his property at Palating Street sold by Palaniappa Chetty. ${ }^{65}$

While towkays Chong Boo Hin and Chong Ah Boo made desperate pleas through their petitions, little could be done for them. The judicial system gave the Chettiars an advantage to secure warrants and judgments on mortgage defaults coupled with auctions and foreclosures. British officials were bound by their own legal processes and rarely deviated from the documents on hand.

Nonetheless, the Chettiars also encountered difficulties with their auctions costing them at times because of technicalities of the law overlooked by some. A case in point was on January 5, 1893, when Chan Chee Hin, heir and executor to the estate of Lim Teck Hee "won his case" against a "Chetty." 66 Chan Chee Hin, executor of Lim Teck Hin was not the only one who resorted to legal proceedings in making it difficult for the Chettiars to take possession of estates pledged to them by towkays or tycoons for loans they had obtained. Towkay Hui Lim Kheh of Chop Kwong Yan Cheung did likewise with regards to Tamby Samy Chetty who took over his bullock cart and rice. Towkay Hui thereafter took up a summons against Tamby Samy Chetty on February 26, 1896 for stealing his valuables. ${ }^{67}$

Nonetheless, in most of these suits, the Chettiars usually received judgments from colonial Magistrates in their favour. More often than not, towkays or tycoons were desperate to retain their possessions after the Chettiars resorted to court proceedings.

\section{Conclusion}

In concluding, several significant themes emerged about the nuances of Chettiar finances at British Malaya from the mid-1870s to early 1890s. They not only accumulated a significant diversity of assets throughout the long depression years. More importantly, through powers of attorney, they also added additional sources of collateral like the salaries and pensions of sultans, rajas and hajis as well as wakaf land. Their credit instrument of chetty's insurance bond gave them security over ships and cargoes. They had also come to acquire physical assets that included properties, hotels, limekiln, trinkets, pawns, bullock carts and commodities such as rice and coffee to back up their credit standing.

From table 5 overleaf, it is clear the Chettiars occupied a prominent role in the financial economy of British Malaya from the mid 1870s to early 1890s from the assets they accumulated as collateral. They worked with a variety of people who included sultans, penghulus, ship captains, tycoons, shopkeepers and farmers in their midst as important networks through their informal financing. 
Table 5: Chettiar Collateral Secured via Asset Accumulation, mid-1870s-early 1890s

\begin{tabular}{|c|c|c|c|}
\hline Name & Collateral & Location & Year \\
\hline $\begin{array}{l}\text { Allagappah } \\
\text { Chetty \& Anor. }\end{array}$ & $\begin{array}{l}\text { Firm of Kavena Chana Shellapah Chitty and } \\
\text { partners seizing Sultan Allie Iskandar Shah } \\
\text { pensions }\end{array}$ & Johore & 1876 \\
\hline $\begin{array}{l}\text { Armoogum } \\
\text { Chetty }\end{array}$ & $\begin{array}{l}\text { Black Diamond ship from Lee Chong Tee \& } \\
\text { Anor. through chetty's insurance bond }\end{array}$ & Singapore & 1881 \\
\hline Verappa Chetty & $\begin{array}{l}\text { Charles Jules ship from Joseph Charles } \\
\text { Angles and Ventre through chetty's insurance } \\
\text { bond }\end{array}$ & Penang & 1881 \\
\hline Meyappa Chetty & Rice from Tradesman Khoo Been Teen & Penang & 1881 \\
\hline Raman Chitty & $\begin{array}{l}\text { S.L. Rapid ship from Sheikh Abbas and Hadji } \\
\text { Abdul Samad through chetty's insurance } \\
\text { bond }\end{array}$ & Singapore & 1883 \\
\hline $\begin{array}{l}\text { Komarapah } \\
\text { Chetty }\end{array}$ & $\begin{array}{l}\text { Lands at Rope Walk Lane from Mortgage to } \\
\text { Mohamed Sham }\end{array}$ & Singapore & 1884 \\
\hline Raman Chitty & $\begin{array}{l}\text { Lands at Bridge Street from Nonia Lim Chee } \\
\text { without knowledge of her husband Dr Nain } \\
\text { Boon Keow }\end{array}$ & Penang & 1885 \\
\hline Meyappa Chetty & $\begin{array}{l}\text { Property of Doral and Lesslar through } \\
\text { fraudulent title deed }\end{array}$ & Penang & 1886 \\
\hline $\begin{array}{l}\text { Narainen Chetty } \\
\text { \& Anor. }\end{array}$ & Property of Kundoo Mah in trust to Jenaiboo & Penang & 1888 \\
\hline Savavathy Chetty & Tongkangs belonging to Nagore Gunny & Penang & 1888 \\
\hline Karupen Chitty & $\begin{array}{l}\text { Bullock carts with Nagamuttoo Sarwag as } \\
\text { surety and Chrisnamuthoo Pillay as owner }\end{array}$ & Selangor & 1890 \\
\hline $\begin{array}{l}\text { Annamallay } \\
\text { Chetty }\end{array}$ & $\begin{array}{l}\text { Batu Road home belonging to towkay Chong } \\
\text { Boo Hin }\end{array}$ & Selangor & 1890 \\
\hline Palaniappa Chetty & $\begin{array}{l}\text { Home belonging to Palaniappa Chetty to } \\
\text { towkay Chong Ah Boo }\end{array}$ & Selangor & 1891 \\
\hline Verappa Chetty & $\begin{array}{l}\text { Power of Attorney over Salaries and Pensions } \\
\text { of Rajas and Hajis }\end{array}$ & Selangor & 1892 \\
\hline $\begin{array}{l}\text { Tamby } \\
\text { Chetty }\end{array}$ & $\begin{array}{l}\text { Bullock cart and rice belonging to towkay Hui } \\
\text { Lim Kheh of Chop Kwong Yan Cheung }\end{array}$ & Selangor & 1896 \\
\hline
\end{tabular}

Source: Compiled from data at HMSCSS, vols. $i$-iv, SSSF, SSR, COR, PLCSS.

With the onset of a global economic depression by the mid-1870s, collaboration for economic benefits took on varied meanings for mercantile communities at British Malaya. The concept of collaboration may have gained prominent usage at British Malaya after World War 2. Yet, the very definition of the word collaboration ${ }^{68}$ also suggests two disparate applications during a much earlier period. On the one hand, collaboration simply meant cooperation as in forming partnerships with colonial authorities for mutually beneficial relationships. The obverse is also true with collaboration defined as traitorous cooperation through a nuanced form of complicity between merchants, colonial officials, local rulers and communities in unlicensed articles. During the economic turmoil of the long depression years, some Chettiars also apparently collaborated with merchants, colonial officials, local rulers and communities in unlicensed activities. In similar vein, some Chettiars also cooperated closely with the colonial authorities as informers. Whatever the viewpoint, it was 
often commercial profit that mattered most to all parties concerned be it merchants, kings, colonial officials or local communities. This was clearly visible from the nuances of Chettiar finances at British Malaya throughout the period of a long depression from the mid-1870s to early 1890 s.

\section{Notes}

${ }^{1}$ For ease of reference, British Malaya is used as a generic term to embody states within the Malay Peninsula from the late $18^{\text {th }}$ century. This would include the period covering British rule within the Straits Settlements and other Malay States, Federated Malay States and Malayan Union. See Frank A. Swettenham, Late Governor \& $c$. of the Straits Colony \& High Commissioner for the Federated Malay States with a specially compiled map, numerous illustrations reproduced from photographs \& a front piece in photogravure, British Malaya, London: John Lane The Bodley Head, 1906, pp. 216-217.

${ }^{2}$ Hans-Dieter Evers and Jayarani Pavadarayan, Ascetism and Ecstasy: The Chettiars of Singapore, Working Papers, No. 79, University of Bielefeld, Faculty of Sociology, 1983/84, p. 2; Hans-Dieter Evers, "Chettiar Moneylenders in Southeast Asia," in Denys Lombard and Jean Aubin ed, Asian Merchants and Businessmen in the Indian Ocean and the China Sea, Oxford University Press, 2000, p. 200. The third varna or colour in the four major status and sub-divisions of Hindu society. David West Rudner, "Religious Gifting and Inland Commerce in Pre-Colonial South India”, Journal of Asian Studies, 46, 2 (1987), pp. 361-379. Chitty, Chetty are Anglicized forms derived from British Malayalam Chetti. See Henry Yule and A.C. Burnell, Hobson-Jobson: a glossary of colloquial Anglo-Indian words and phrases, ed. William Crooke, London: John Murray, 1903, pp. 189-190. Chettiar is not a plural form as Dr. Lakshmi-Chandra Jain, Indigenous Banking in India, London: Macmillan, 1929, p. 30 had stated; ar is a Tamil suffix meaning respectability. In English, Chettiar is often spelled with a y instead of i cited in Report of the Burma Provincial Banking Enquiry Committee, "Banking and Credit in Burma," BPBEC, vol. I, Rangoon: Suprintendent of Government Printing, 1930, pp. 189, 206. For this research, the term Chettiars is used unless otherwise stated in source.

${ }^{3}$ The nine kovils are Hayaththukuch, Maththur, Vairavan, Iraniyar, Pillayarpatti, Neman, Huppaikudi, Suraikudi and Velangkudi. See E. Thurston, Caste and Tribes of Southern India, Madras: Government Press, 1909, pp. 250, 253. See chapter 4, David West Rudner, Caste and Capitalism in Colonial India: The Nattukottai Chettiars, Berkeley and Los Angeles, California: University of California Press, 1994; C.H Rau, "The banking castes of Southern India," Indian Review, Madras, 8/8, August (1907). For example, Palaniappa, Murugappa and Ramanathan in partnership would style their firm with the initials P.M.RM. Chettiar. It was customary that the name Ramanathan was denoted as RM. Also the Therkuvattagai Chettiars had a slight variation to their operation and system of accounting vis-à-vis the Nattukottai Chettiars. However, it was not always easy to trace all these vilasams because each partner could also work in multiple firms and across different regions. This also explains why not all Chetty, Chitty, Chetti and Chettiar names had vilasams. See BPBEC, vol. I, 1930, pp. 204206.

${ }^{4}$ See Paul H. Kratoska, "The Chettiar and the Yeoman, Singapore", Institute of Southeast Asian Studies, Occasional Paper no. 32 (1975), pp. 1-39; Paul H. Kratoska, "The Peripatetic Peasant and Land Tenure in British British Malaya," Journal of Southeast Asian Studies, vol. 16, No. 1, Mar (1985), pp. 16-45; Paul H. Kratoska, "Chettiar Moneylenders and Rural Credit in British Malaya," Journal of the Malaysian Branch of the Royal Asiatic Society, vol. 86, part 1, no. 304, June (2013), pp. 61-78. A good overview of their economic contributions is by Hans-Dieter Evers, "Chettiar Moneylenders in Southeast Asia", in Denys Lombard and Jean Aubin eds., Asian Merchants and Businessmen in the Indian Ocean and the China Sea, Oxford University Press, 2000, pp. 197-220; Hans-Dieter Evers, Kullurwandel in Ceylon, Lutzyer: Baden-Baden, 1964. See also Hans-Dieter Evers and Jayarani Pavadarayan, Ascetism and Ecstasy: The Chettiars of Singapore, Working Papers, No. 79, University of Bielefeld, Faculty of Sociology, 1983/84; Hans-Dieter Evers, Jayarani Pavadarayan, and Heiko Schrader, "The Chettiar Moneylenders in Singapore," in Hans-Dieter Evers and Heiko Schrader ed., The Moral Economy of Trade. Ethnicity and Developing Markets, London and New York: Routledge, 1994, pp. 198-207; Hans-Dieter Evers and Jayarani Pavadarayan, "Religious Fervour and Economic Success: The Chettiars of Singapore," in Kernial Singh Sandhu and A. Mani ed. Indian Communities in Southeast Asia, Singapore: Times Academic Press, 2006, pp. 847-865; Raman Mahadevan, "Pattern of Enterprise of Immigrant Entrepreneurs: A Study of Chettiars in British Malaya, 1880-1930," Economic and Political Weekly, vol. 13, No. 4/5, Jan 28-Feb 4, 1978, pp. 146-152; Raman Mahadevan, "Immigrant Entrepreneurs in Colonial Burma - An Exploratory Study of the Role of Nattukottai Chettiars of Tamil Nadu, 
1880-1930," IESHR, vol. xv, No. 3, 1978, pp. 329-358. Some sections are in the books of Sinnappah Arasaratnam, Indians in British Malaya and Singapore, Oxford University Press, 1970; K. S. Sandhu, Indians in British Malaya: Immigration and Settlement, 1786-1957, London: Cambridge University Press, 1969 and Rajeshwary Ampalavanar Brown, Capital and Entrepreneurship in Southeast Asia, London: Macmillan Press 1994, pp. 173-188; D. Muthusamy, Sri Thendayudapani Temple, Singapore, Academic Exercise, Department of Social Studies, University of British Malaya, 1958; Umadevi d/o Prabaharan exchanged useful insights with me throughout the course of her dissertation Kegiatan Peminjaman Wang Chettiar Di Tanah Melayu, 1896-1957 trans. Chettiar Moneylending Activities in British Malaya, 1896-1957, PhD thesis, University of British Malaya, 2013. A narrative on their traditions is in S.P. Thinnappan and Soundara Nayaki Varavan, Nagarathars in Singapore, Navaso Pte Ltd, 2010.

${ }^{5}$ Edgar Thurston, Caste and Tribes of Southern India, Madras: Government Press, 1909; S. Chandrasekhar, The Nagarathars of South India: An Essay and a Bibliography on the Nagarathars in Indian and Southeast Asia, Madras: Macmillan Company of India, 1980; M. Nadarajan, "The Nattukottai Chettiar community and Southeast Asia," Xavier S. Thaninayagam ed., vol. 1, In Proceedings of the First International ConferenceSeminar of Tamil Studies, Kuala Lumpur: International Association of Asian Research, 1966; Lakshmi-Chandra Jain, Indigenous Banking in India, London: Macmillan, 1929, pp. 10-274; V. Krishnan, Indigenous Banking in South India, Bombay: State Cooperative Union, 1959, pp. 15-208; U. Tun Wai, Burma's Currency and Credit, Department of Economics, Rangoon: University of Rangoon, 1962, pp. 40-236; W.S. Weerasooria, The Nattukottai Merchant Bankers in Ceylon, Tisara Parkasakayo, Dehiwala, 1973, pp. xxv-131.

${ }^{6}$ Michael Adas, The Burma Delta: Economic Development and Social Change on an Asian Rice Frontier, 1812 1941, Madison: University of Wisconsin Press, 1974, pp. 66-253; Phillip Siegelman, Colonial Development and the Chettiar: A Study in Political Economic Ecology of Modern Burma, PhD Thesis, University of Minnesota, 1962; J.R. Andrus, Burmese Economic Life, Stanford: California University Press, 1947, pp. 15-360; C.L. Cooper, Moneylenders and the Economic Development of Lower Burma - an Exemplary Historical Study of the Role of the Indian Chettiars, PhD Thesis, Washington: The American University, 1959. See chapter 4 in Christopher John Baker, An Indian Rural Economy, 1880-1955, Oxford: Oxford University Press, 1984, pp. 281-290 that highlights Nakarattar commercial practices within Madras.

${ }^{7}$ Medha Malik Kudaisya, "Marwari and Chettiar Merchants, c. 1850s-1950s: Comparative Trajectories", in Medha Malik Kudaisya and Ng Chin-Keong eds., Social Sciences in Asia, Volume 24: Chinese and Indian Business: Historical Antecedents, Boston: Brill Academic Publishers, 2010, pp. 85-120.

${ }^{8}$ More recent ethno-historical studies include those by Arjun Appadurai, "Right and left hand castes in South India", Indian Economic and Social History Review, 11, 2-3 (1974), pp. 216-259; Carol Appadurai Breckenridge, The Sri Minakshi Sundareshvarar Temple: Worship and Endowments in South India, 1833-1925, PhD Thesis, University of Wisconsin, Madison , 1976; Nicholas B. Dirks, The Hollow Crown: Ethnohistory of an Indian Little Kingdom, Cambridge: Cambridge University Press, 1987; Pamela G. Price, Resource and Rule in Zamindari South India, 1802-1903, PhD Thesis, University of Wisconsin, 1979. On cultural and religious interaction through the temple, see Manuel Moreno, Murugan, a God of Healing Poisons: The Physics of Worship in a South Indian Center for Pilgrimage, Ph.D. dissertation, University of Chicago, 1984; McKim Marriott and Manuel Moreno, "Humoral transactions in two South Indian Cults," in McKim Mariott ed., India Through Hindu Categories, New Delhi: Sage Publications, 1990. See also McKim Marriott and Manuel Moreno, "Contributions to Indian Sociology," N.S. 24, No. 2 (1990), pp. 149-69. Good works on kinship and kingship aspects are by Louis Dumont, "Hierarchy and marriage alliance in South Indian Kinship," Occasional Papers of the Royal Anthropological Institute, No. 12, London: Royal Anthropological Institute, 1957, Reprint, 1983; McKim Marriot, "Hindu transactions: Diversity without dualism," in B. Kapferer ed., Transaction and Meaning: Directions in the Exchange and Symbolic Behaviou, Philadelphia: Ishi, 1976; Brenda Beck, Peasant Society in Konku: A Study of Right and Left Sub-castes in South India, Vancouver: University of British Columbia Press, 1972; A.M. Hocart, Caste: A Comparative Study, London: Methuen, 1950.

${ }^{9}$ David West Rudner, Caste and Capitalism in Colonial India: The Nattukottai Chettiars, Berkeley and Los Angeles, California: University of California Press, 1994; David West Rudner, "Religious Gifting and Inland Commerce in Pre-Colonial South India, Journal of Asian Studies, 46, 2 (1987), pp. 361-379; David Rudner, Caste and Commerce in Indian Society: A Case Study of Nattukottai Chettiars, 1600-1900, PhD Thesis, University of Pennsylvania, Philadelphia, 1985.

${ }^{10}$ Rajat Kanta Ray, "Asian Capital in the Age of European Domination: The Rise of the Bazaar, 1800-1914," Modern Asian Studies, 29, 3 (1995), pp. 449-554; Rajat Kanta Ray, "The bazaar: changing structural characteristics of the indigenous section of the Indian economy before and after the Great Depression," Indian Economic Social History Review [IESHR], 25, 3(1998), pp. 263-318; Clifford Geertz, Pedlars and Princes. Social Change and Economic Modernization in Two Indonesian Towns, Chicago, 1963, pp. 21-157; Clifford Geertz, "Suq: the bazaar economy in Seffrou," in Clifford Geertz, Hildred Geertz and Lawrence Rosen, Meaning and Order in Moroccan Society, Three essays in Cultural Analysis, Cambridge, 1979, pp. 235-510; 
Ashin Das Gupta, Indian Merchants and the Decline of the Surat c. 1700-1750, Wiesbaden, 1979, pp. 10-15; C.A. Bayly, "Indian merchants in a 'traditional' setting: Benares 1780-1830," in The Imperial Impact: Studies in the Economic History of Africa and India ed. A.G. Hopkins and Clive Dewey, London: Athlone Press for the Institute of Commonwealth Studies, 1978, pp. 171-193; Thomas A. Timberg and C. V. Aiyar, "Informal Credit Markets in India," Economic Development and Cultural Change, vol. 33, no. 1, (Oct 1984), pp. 43-59; Claude Markovits, "Structure and Agency in the World of Asian Commerce during the Era of European Colonial Domination (c. 1750-1950)," and "Spatial and Temporal Continuities of Merchant Networks in South Asia and the Indian Ocean", both in Journal of the Economic and Social History of the Orient, vol. 50, no. 2/3 (2007), pp. 106-123; Sean Turnell, Fiery Dragons, Moneylenders and Microfinance in Burma, Nordic Institute of Asian Studies: NIAS Press, 2009, p. 20.

${ }^{11}$ See chapter 6 of Christine Dobbins, "From Madras to Burma: The Nattukottai Chettiars and Development 1852-1939," Asian Entrepreneurial Minorities: Conjoint Communities in the Making of the World Economy, 1570-1940, Routledge Curzon Press, 1996; Bernard Semmel, Imperialism and Social Reform: English Social Imperial Thought, 1895-1914. London, 1960 cited in Wolfgang Mommsen, Theories of Imperialism, London: Weidenfeld and Nicolson, 1981, p. 8, fn. 11; Werner Sombart, The Jews and Modern Capitalism, with a new Introduction by Samuel Z. Lausner, trans. by M. Epstein, New Brunswick and London: Translation Books, 1982, pp. xv-cv, 3-21; Max Weber, Economy and Society, vol. 2, University of California Press, 1978, p. 920; Joseph Schumpeter, Imperialism and Social Classes, ed. Paul M. Sweezy, Oxford, 1951; Gunder Franz, "World Division of Labor and Balances of Trade" in Reorient: Global Economy in the Asian Age, University of California Press, 1998; Immanuel Wallerstein, "Culture as the Ideological Battleground of the Modern World System," in Theory, Culture and Society, vol. 7, 1990; Immanuel Wallerstein, "The Rise and Future Demise of the World Capitalist System: Concepts for Comparative Analysis," Comparative Studies in Society and History, 16, 1974; Immanuel Wallerstein, "The Rise and Future Demise of World-Systems Analysis." Paper delivered to the $91^{\text {st }}$ Annual Meeting of the American Sociological Association, New York, August, 1997.

12 J.C. Van Leur, Indonesian Trade and Society: Essay in Asian Social and Economic History, English ed., The Hague, Bandung: W. van Hoeve, 1955, pp. 201, 204, 205, 214, 220; F. Braudel, "Civilization and Capitalism $15^{\text {th }}-18^{\text {th }}$ Century," vol. II, The Wheel of Commerce, London: Fontana Press, 1985, pp. 376-378. Read Introduction of Wu Xiao An, Chinese Business in the Making of a Malay State, 1882-1941: Kedah and Penang, new ed., Singapore: NUS Press, 2010, pp. 1-18.

${ }^{13}$ C.M. Turnbull, The Straits Settlements, 1826-67: Indian Presidency to Crown Colony, University of London: The Athlone Press, 1972, pp. 242-251; J. Low, "An Account of the Origin and Progress of the British Colonies in the Straits of Malacca," James Richard Logan ed., Journal of the Indian Archipelago and Eastern Asia [henceforth JIA], iii (1849), pp. 559-617; iv, (1850), pp. 11-26, 106-118, 360-379; See the works of V.T. Harlow and Nicholas Tarling cited in Ooi Keat Gin ed., The Works of Nicholas Tarling on Southeast Asia, 6 vols. "The Merest Pustule and Other Concerns: Britain and the Malay Peninsula," vol. IV, London: Routledge, Taylor and Francis Group, 2013, pp. 10-24; Carl Trocki, Prince of Pirates: The Temenggongs and the Development of Johor and Singapore, 1784-1885, Singapore: NUS Press, 2007, pp. 1-55; B.W. Andaya, To Live as Brothers: Southeast Sumatra in the Seventeenth and Eighteenth Centuries, Honolulu: University of Hawaii Press , 1993; Wu Xiao An, Chinese Business in the Making of a Malay State, 1882-1941: Kedah and Penang, Singapore: NUS Press, 2010. See Nicholas Tarling, "Malaya in British History" Journal of the Malaysian Branch of the Royal Asiatic Society, 62: (1989), pp. 11-20 cited in Ooi Keat Gin ed., The Works of Nicholas Tarling on Southeast Asia 2013, p. 48.

14 The Marquess of Lansdowne as Chair in examination of John Crawfurd Esquire, 13.06.1820, East India Company, Report from the Select Committee of the House of Lords to inquire into the means of extending and securing the FOREIGN TRADE of the country, and to report to the House; together with the Minutes of Evidence taken in Sessions 1820 and 1821, before the said Committee: 11.04.1821, London: House of Commons, 07.05.1821, p. 18.

15 Tabulated from The Singapore and Straits Directory for 1881 (NLB, 2006); Government Gazettes in 1883, 1900 and 1910 in The Singapore Government Gazette (NLB, 1867).

${ }^{16}$ A good account of the long depression known as the first great depression is in Hans Rosenberg, "Political and Social Consequences of the Great Depression of 1873-1896 in Central Europe," The Economic History Review, 13, 1/2, Blackwell Publishing 1943, pp. 58-73. A.E. Musson, "The Great Depression in Britain, 18731896: A Reappraisal," The Journal of Economic History 19, 2, Cambridge University Press 1959, pp. 199-228. Peter Termin, Lessons from the Great Depression, Cambridge: MIT Press 1989, provides a good overview of next great depression of the early 1930s took precedence after the long depression. Post-war inflation, rampant speculative investments, overwhelmingly in railroads, a large trade deficit, ripples from economic dislocation in Europe resulting from the 1870 to 1871 Franco-Prussian War, property losses in the 1871 Chicago and 1872 Boston fires, and other factors put a massive strain on bank reserves, which plummet in New York City during 
September and October 1873 from \$50 million to \$17 million. See details in Neil Faulkner, A Marxist History of the World: From Neanderthals to Neoliberals (Pluto 2013).

${ }^{17}$ Details of loans in Abdul Wahab bin Mohamat Allie \& c. v. Sultan Allie Iskandar Shah [Sultan of Johore], Malacca, May 4, 1843 in in James William Norton Kyshe, Esq., Acting Magistrate of the Said Court of Malacca, edited and reported with a Judicial Historical Preface From 1786 to 1884, His Majesty's Supreme Court of the Straits Settlements [HMSCSS], vols. i-iv,vol. i (1885), pp. 301-302.

18 "Kavena Chana Shellapah Chitty" was an agency firm of partners. James Guthrie Davidson was representing Allagappah Chetty, a partner in the firm. Details in Allagappah Chetty and Anor, v. Tunku Allum Bin Sultan Allie Iskander Shah, HMSCSS, Singapore, Dec 29, 1881, vol. i (1885), p. 521.

${ }^{19}$ Bengal Political Consultations [B. Pol.] Range 127, vol. 31: 08.03.1836, nos. 2-3.

${ }^{20}$ Details of this highly interesting case are in HMSCSS, Allagappah Chetty and Anor. v. Tunku Allum Bin Sultan Allie Iskander Shah, Singapore, Dec 29, 1881, vol. i (1885), pp. 520-533.

${ }^{21}$ Straits Settlements (Repeal) Act 1946, 9\&lo geo 6 c 37, (United Kingdom).

${ }^{22}$ Judge J. Wood in Letchman Chetty v. Narainan Chetty in HMSCSS, Penang, Oct 21, 1878, vol. i, 1885 , p. 468.

${ }^{23}$ Armoogum Chetty v. Lee Chong Tee \& Anor, in HMSCSS, Singapore, May 15, 1868, vol. i, 1885, pp. 181184.

${ }^{24}$ Verappa Chetty v. Ventre in HMSCSS, Penang, February 25, 26, 27, 1868, vol. i, 1885, pp. 174-181.

${ }^{25}$ Carl A. Trocki, Opium and empire: Chinese society in Colonial Singapore, 1800-1910, Cornell University Press, 1990, examines how opium was a lynchpin in the class struggle at Singapore from a colonial policy viewpoint. See also Carl A. Trocki, "Opium and the Beginnings of Chinese Capitalism in Southeast Asia," Journal of Southeast Asian Studies, 33, 2 (June, 2014), pp. 297-314; Carl A. Trocki, Opium, Empire and the Global Political Economy: A Study of the Asian Opium Trade, 1750-1950, Psychology Press, 1999. James F. Warren, Rickshaw Coolie: A People's History of Singapore, 1880-1940, Singapore, 2003, takes a subaltern view of how it affected society in general. James R. Rush, Opium To Java: Revenue Farming and Chinese Enterprise in Colonial Indonesia, Cornell University Press, 1990, sees how opium entered society and the state benefitted from it. Eric Tagliacozzo, Secret Trades, Porous Borders: Smuggling and States Along a Southeast Asian Frontier, 1865-1915, Yale University Press, 2007, pp. 185-289 outlines in great detail how each of the illicit articles in narcotics, counterfeit coins and currencies as well as human traffic affected the society at large throughout Southeast Asia.

${ }^{26}$ Details in Records of the Government of the Straits Settlements [SSR] preserved in the Raffles Library, Singapore. See Candapha Chettiar's petition to Robert Ibbetson, transcribed is at Appendix 1. SSR, Series M, Letters to and from Bengal, 1823-61, 12 vols, 31.08.1831, M.6/120-21. See also microform, Stack \# R0012369, Singapore: Imprint-National Library Archives, 1987.

${ }^{27}$ Deposition of super cargo made on 28.07.1813 at Prince of Wales Island; Deposition of Coomba Toomby and Noor Mohamed on board Annapoorney owned by Candappa made on 24.07.1813. Both in Straits Settlements Factory Records [SSFR as distinct from SSR], vol. 40, 1805-1830 (London: IOL): 24.08.1813.

${ }^{28}$ Details in Selangor State Secretariat Files [SSSF], 1875-1941 (Kuala Lumpur: Government Printing Office, NAM) See SSSF, 1957/0003594, Magistrate 1643/84, Forwarding Disposition re: the trial of Mr. Arthur J. Perks, 07-Aug-1884 to 08-Sep-1884.

29 “Atavisme der O.I. Compagnie” (1884); “Opium Reglement. Penbaar Ambtnaar Omkoopin,” IWvhR, no. 846, 1879. Both cited in (Tagliacozzo, 2007: fn.32-33, 192).

${ }^{30}$ SSSF, 1957/0003552, MISC 1576/84, Monies Owing by Arthur J. Perks to Verappa Chetty, 7-Aug-1884

${ }^{31}$ Mercantile Bank and Hongkong Shanghai Bank Records, HQ LOHII 0125, Inspector's reports for the following branches: Hamburg, London, Bombay, Calcutta, Penang, Rangoon, Ipoh, Kuala Lumpur, Malacca, Sourabaya, Johore, Singapore, Batavia, Bangkok, Yokohama, Saigon, 1875 (London: HSBC Archives).

${ }^{32}$ Perak Government Gazette, 1881:161; Bawasah Merican v. Kootyan Chetty, November 14, 1887 in James William Norton Kyshe, Esq., Acting Magistrate of the Said Court of Malacca, edited and reported with a Judicial Historical Preface From 1786 to 1884, His Majesty's Supreme Court of the Straits Settlements [HMSCSS], vol. i-iv, 1808-84, vol. i, Singapore: Singapore and Straits Printing Office, 1885, pp. 321-322.

${ }_{33}$ Mercantile Bank and Hongkong Shanghai Bank Records, HQ LOHII 0125, Inspector's reports for the following branches: Hamburg, London, Bombay, Calcutta, Penang, Rangoon, Ipoh, Kuala Lumpur, Malacca, Sourabaya, Johore, Singapore, Batavia, Bangkok, Yokohama, Saigon, 1875 (London: HSBC Archives).

${ }^{34}$ See Ahvena Ravena Mana Aroomoogum Chetty c. Lim Ah Hang, Ah Gee and Chop Lee Whatt, Straits Settlements Legal Reports, vol. 2, Singapore: Singapore and Straits Printing Office, 1894, p. 80.

${ }^{35}$ Lysa Hong, Thailand in Nineteenth Century: Evolution of the Economy and Society, Singapore, 1984, pp. 8889. In effect, at Selangor alone, some Chinese revenue farms yielded a net profit equal to one-fifth of the total revenue collected in the state. Wong Lin Ken, The British Malayan Tin Industry to 1914, with Special Reference to the States of Perak, Selangor, Negri Sembilan and Pahang, Tuscon, 1965, p. 251. 
${ }^{36}$ Bawasah Merican v. Kootyan Chetty, November 14,1887, HMSCSS, vol. iv, 1885, p. 321; Doral v. Lesslar In re Meyappa Chetty, Penang, September 8, 1886, HMSCSS, vol. iv, 1890, pp. 183-185.

${ }^{37}$ Arsip Nasional Republik Indonesia [ANRI], Jakarta (Indonesia) See ANRI, Aceh no. 12, Dutch Consul Penang to Governor General, Netherlands East Indies, 7 Jan 1876, no. 83, G/Confidential, in Dept. van Oorlg VII, no. 192, 31-Jan-1876 cited in (Tagliacozzo 2007: fn. 26, 203; 224).

${ }^{38}$ Khoo Aing Hong v. Meyappa Chetty, Puteh v. Khoo Aing Hong, December 13, 1880, HMSCSS, vol. iii, 1885 , pp. 124-126.

${ }^{39}$ SSSF 445/1905; SSSF 3709/1907.

${ }^{40}$ The Spanish dollar currency remained in circulation into the early 1900s even after the Straits dollar came into being after the formation of the Federated Malay States. In fact the Straits dollar implemented from 1898 to 1939 was quite weak and pegged at two shillings four sterling pence in 1906. See Owen Linzmayer, "Straits Settlements," The Banknote Book (San Francisco, California: www.BanknoteNews.com: 2013)

${ }^{41}$ Verapah Chetty v. Lim Swee Choe \& Anor, Penang, August 4, 1874, HMSCSS, vol. i, 1885, pp. 378-380.

${ }^{42}$ Coomarapah Chetty v. Kang Oon Lock, Penang, June 19, 1868, HMSCSS, vol. i, 1885, pp. 314-321.

${ }^{43}$ Meyappa Chetty v. Khoo Bean Teen \& Ors., Penang, July 11, 1881, HMSCSS, vol. i, 1885, pp. 510-511.

${ }^{44}$ Mohamed Sham v. Komorapah Chetty., Penang, October 22, 1884, HMSCSS, vol. iii, 1885, pp. 186-188.

${ }^{45}$ SSSF, 1957/0003040, Klang 425/84, Enclosing a copy of a form of mortgage entered in Singapore by Sheikh Abbas and Hadji Abdul Samad with Navena Moona Raman Chitty with reference to a steam launch S.L. Rapid, 22-Feb-1884 to 25-Dec-1884.

${ }^{46}$ See Resident's note on inner file cover, 18-Mar-1884 in SSSF, 1957/0003040, Klang 425/84.

${ }^{47}$ Nain Boon Keow v. Letchmann Chetty \& Anor, Penang, May 5, 1888, HMSCSS, vol. iv, 1890, pp. 85-88.

${ }^{48}$ Doral v. Lesslar In re Meyappa Chetty, Penang, September 8, 1886, HMSCSS, vol. iv, 1890, pp. 183-185.

${ }^{49}$ Jenaiboo v.Narainen Chetty \& Anor, Penang, April 6, 1888, HMSCSS, vol. iv, 1890, pp. 359-364; Shenayah Chetty Anor, v. Veyna Sultan Mahomed, Penang, September 10, 1890, HMSCSS, vol. iv, 1890, pp. 663-665.

${ }^{50}$ Nagore v. Nagore Gunny In re Savavathy Chetty, Penang, May 20, 1890, HMSCSS, vol. iv, 1890, pp. 595596.

${ }^{51}$ Coopang Chetty v. Veera Padiachee and others, Penang, April 12, 1888, HMSCSS, vol. iv, 1890, p. 365.

${ }^{52}$ Case details in Coopang Chetty v. Veera Padiachee and others, Penang, April 12, 1888, HMSCSS, vol. iv, 1890, pp. 364-368.

${ }^{53}$ For details, read F.A. Swettenham, British Resident Selangor to H.C. Belfield, Chief Collector \& Magistrate Selangor in SSSF, 1957/0012529, MISC 2754/88, Telegram to Syed Zui, "What about Hotel Chitty Brothel lease? Please reply," 08-Oct-1888 to 22-Nov-1888.

${ }^{54}$ SSSF, 1957/0012660, K. Sel. 2884/88, Encloses Application from Raja Itam for a personal loan of $\$ 600$ to enable him to recover from pawn a number of trinkets pledged to Verappa Chitty, 15-Oct-1888 to 16-Oct-1888. F.A. Swettenham, Resident Selangor reply to J.P. Rodger, Acting Collector, Klang, Selangor in SSSF, 1957/0012660, K. Sel. 2884/88.

55 SSSF, 1957/0016696, NATIVE 3106/89, trans. Jawi to Malay, Petition by Haji Hassan in Malay asking assistance from British Resident, F.A. Swettenham in his case with Haraina Chitty, 10-Sep-1889.

${ }^{56}$ SSSF 6019/1907; SSSF 215/1907; SSSF 2647/1909.

${ }^{57}$ SSSF, 1957/0014376, MISC 781/89, Appeal against judgment entered against him at the suit of one Karpen Chitty, 05-Mar-1889; SSSF, 1957/0016153, 2559/89, Baboo Mandore petition to Ag British Resident on conflict with Palaniappa Chitty and Chelappa Chitty, 06-Aug-1889.

${ }^{58}$ SSSF, 1957/0020583, MISC 5592/90, Ramasamy Valee to British Resident Selangor, W.G. Maxwell, Asking for a reply to petition re: his bags of coffee taken by Sivarama Chetty, 13-Sep-1889. British Resident Selangor, W.G. Maxwell to Ramasamy Valee, 18-Sep-1890 in SSSF, 1957/0020583, MISC 5592/90.

${ }^{59}$ The Straits Times, "Pahang News," 18-June-1889, p. 3.

${ }^{60}$ SSSF, 1957/0009532, MISC 2979/87, Nagamuttoo Swamy notice from Karupen Chitty for certain sums of money for which he stood as surety for his friend Crisnamuttoo Pillay, 25-Nov-1887.

${ }^{61}$ Nagamuttoo Swamy notice from Karupen Chitty for certain sums of money for which he stood as surety for his friend Crisnamuttoo Pillay, 25-Nov-1887 in SSSF, 1957/0009532, MISC 2979/87.

${ }^{62}$ Mootyah Chetty v. Yacob In re Nyah Hamzah, Penang, February 10, 1890, HMSCSS, vol. iv, 1890, pp. 568569.

${ }^{63}$ Nain Boon Keow v. Letchmann Chetty \& Anor, Penang, May 5, 1888, HMSCSS, vol. iv, 1890, pp. 85-88, was just one of many other examples in legal records.

${ }^{64}$ Chong Boo Hin Petition to W.E. Maxwell, 1-Apr-1891, SSSF, 1957/0024106, MISC 2253/91, Mortgage of Chong Boo Hin's House at Batu Road to Annamalay Chetty, 1-Apr-1891 to 20-April-1891. A.T.D. Berrington, Chief Magistrate Selangor to Governor Secretary, 4-April-1891 in SSSF, 1957/0024106, MISC $2253 / 91$. Memos, 6-Apr-1891; 7-Apr-1891, SSSF, 1957/0024106, MISC 2253/91. 
${ }^{65}$ Chong Ah Boo petition to J.P. Rodgers, 22-May-1891, SSSF 1957/0025077 MISC 3424/91, House at Batu Road sold by Palaniappa Chetty for monies due to him, 22-May-1891 to 6-Jun-1891. A.T.D. Berrington, Chief Magistrate Selangor to Governor Secretary, 5-Jun-1891, SSSF 1957/0025077 MISC 3424/91.

${ }^{66}$ A.T.D. Berrington, Chief Magistrate Selangor to Ernest Woodford Birch, Acting Resident Selangor, 5-Jan1893, SSSF 1957/0036775 KUALA LUMPUR 228/93, Estate of Lim Teck Hee, Chan Chee Hin's case with the Chetty, 5-Jan-1893 to 1-Feb-1893; A.T.D. Berrington, Chief Magistrate Selangor to William Hood Treacher, British Resident Selangor, 21-Jan-1893, SSSF 1957/0036775 KUALA LUMPUR 228/93; William Hood Treacher, British Resident Selangor to A.T.D. Berrington, Chief Magistrate Selangor, 30-Jan-1893, SSSF 1957/0036775 KUALA LUMPUR 228/93.

${ }^{67}$ Hui Lim Kheh of Chop Kwong Yan Cheung asking Magistrate to hear case brought by him against a Chetty named Tamby Samy at Kuala Kubu, SSSF 1957/0061956 CH: MISCELLANEOUS 1246/1896.

${ }^{68}$ Oxford Dictionaries Language Matters, Collaboration, 2014, www.oxforddictionaries.com (accessed March 18, 2014); World English Dictionary, Collaboration, 2014, www.dictionary.com (accessed March 18, 2014). 